\title{
Humanistic Motivation A Different Perspective in the EFL Classroom
}

\author{
Patricia López Estrada ${ }^{1}$
}

Colegio Universitario de Puntarenas, Costa Rica

\section{RESUMEN}

Se plantea la relación entre la motivación, la metodología humanística y el nivel de competencia en inglés. Mediante un estudio etnográfico se señalan aspectos motivacionales y de índole humanística que influyen directamente en el aprendizaje del idioma inglés, lo que lleva a óptimos resultados en el sector social observado.

\section{Abstract}

The relationship between motivation, the humanistic approach and English proficiency is addressed. Through an ethnographic study, several motivational and humanistic patterns were seen to influence the learning of English directly. This leads to optimal results in the social sector observed.

Palabras claves: segunda lengua, motivación, educación humanística, enseñanza

Keywords: foreign language, motivation, humanistic approach, teaching

Motivation is one of the most important factors in successful English acquisition. Everybody talks about it, but what does it really mean to be motivated to study English? It means having a real purpose

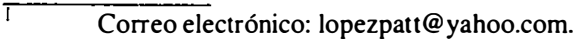


in learning English, or wanting it for a specific reason. It is an affective factor inside the individual and it involves the learner's overall goal or orientation. ${ }^{2}$ In addition to motivation, there are also other factors that influence students' learning directly: emotions, feelings and humanistic perceptions.

William T. Lile wrote:

A caring teacher tries to develop a relationship with the students. If the teacher sees potential in all students, and communicates this well to the students, they will in return build a desire to learn and participate. When the students realize that you are not going to get angry, you are being nice and understanding, and the reason you are trying so hard is because it is important to you that your students learn and do well, the natural human reaction is to reciprocate and do something nice in return. ${ }^{3}$

This passage shows how motivation and humanistic education are key elements in the teaching/learning process. Caring and sharing are valuable resources that English teachers do not take into account; they are considered as unimportant. Nonetheless, they are vital in the EFL environment because they lead to efficient, retainable learning. In addition, motivation and humanistic education promote students' interests in the class and enhance good teacher-student and studentstudent relationships. The following investigation considers how a group of ESL students perceive these two features as fundamental for learning the language. This study presents ethnography research carried out at Colegio Universitario de Puntarenas (CUP), a small community college located in Puntarenas, Costa Rica.

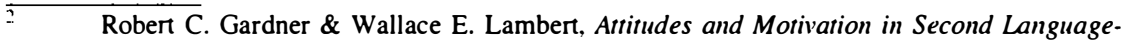
Learning (Rowley, Massachusetts: Newbury House, 1972).

William T Lile, "Motivation in the ESL Classroom," The Internet ESL Journal VIII, 1 (2002), accessed 3 Feb. 2003, <http:iteslj.org/Techniques/Lile-Motivation.html>.
} 


\section{Motivation and Language Learning}

Motivation has been identified as the learner's orientation with regard to the goal of learning a second language. Brown identifies three types of motivation: global motivation (goal of learning L2), situational motivation (situation in which learning takes place) and task motivation (performing particular learning tasks). ${ }^{4}$ If students are motivated, they will achieve their goals easier and faster, and enjoy the experience of learning a second language. Although motivation is a vast and complex subject, simply being aware of the kind of motivation a student has, is of great benefit for that student's acquisition of a second language.

Many have been challenged to investigate this area of study and well-known authorities such as Gardner and Lambert have done research in the field of second language learning. Teachers invest quite a bit of time trying to meet the needs and wants of their students the best they can, thus channeling motivation in directions that are satisfying to the students. ${ }^{5}$ In other words, the methods that teachers use in their classes must be primarily aimed at satisfying what Mallow defined as their hierarchy of needs: psychological, safety, security, stability and acceptance. "If our students are not learning a language as we would like them to, the reason may well be traceable to unsatisfied lower levels of Mallow's hierarchy needs."6 This might be one of the first reasons why a lack of motivation appears. When our needs are not being satisfied, we are not motivated to continue.

Up to this point, needs and wants as guiding points are what we should try to understand as to why motivation is sometimes not present when learning a second language. If we have a need, we think of a

Douglas Brown, Principles of Language and Teaching (Englewood Cliffs: Prentice Hall Regents, 1993) 152-62.

Brown, 153.

Wilga M. Rivers, Communicating Naturally in a Second Language. Theory and Practice in Language Teaching (Cambridge: Cambridge University Press, 1984) 147-54. 
desired goal. When students have an attractive goal in mind, especially a long-term one, they get an internal drive and become motivated. But what is their goal exactly? How do they reach it? How can instructors make learning attractive enough for the students to want to achieve their academic goals? One way is to detect the students' type of motivation. The motivated student is one that finds it easier to be open to a teaching-learning situation. However, sometimes it is not so easy to discern, and here is when I resort to the Gardner's Socio Educational Model ${ }^{\text {? }}$ :

"...motivation is perceived to be composed of three elements. These include effort, desire and affect. Effort refers to the time spent studying the language and the drive of the learner. Desire indicates how much the learner wants to become proficient in the language, and affect illustrates the learner's emotional reaction with regard to language study."

In regard to motivation we can mention four main kinds of motivation: integrative, instrumental, intrinsic and extrinsic motivation. Students who are most successful when learning a target language are those who like the people that speak the language, admire the culture and have a desire to become familiar with or even integrate into the society in which the language is used. ${ }^{8}$ This form of motivation is known as integrative motivation. When someone becomes a resident in a new community that uses the target language in its social interaction, integrative motivation is a key component in helping the leamer to develop some level of proficiency in the language. It is also theorized that "integrative motivation typically underlies successful acquisition of a wide range of registers and a native-like pronunciation."9

\footnotetext{
Robert C. Gardner. Language Attitudes and Language Learning Attitudes Towards Language Variation: Social and Applied Contexts (London: Edward Amold, 1982) 132-47. Jacqueline Norris, "Motivation as a Contributing Factor in Second Language Acquisition" The Internet TESL Journal VII. 6 (June 2001), accessed 6 May 2004, <http://iteslj.org/Articles/ Norris-Motivation.html>.

Edward Finnegan, Language: Its Structure and Use (New York: Harcourt Brace, 1999).
} 
In contrast to integrative motivation, we find the form of motivation referred to as instrumental motivation. This is generally characterized by the desire to obtain something practical or concrete from the study of a second language. With instrumental motivation the purpose of language acquisition is more utilitarian, such as meeting the requirements for school or university graduation, applying for a job, requesting higher payment based on language ability, reading technical material, translation work or achieving higher social status.

While both integrative and instrumental motivation can be essential elements of success, it is integrative motivation which I find to sustain long-term success when learning a second language. ${ }^{10} \mathrm{At}$ CUP, the students who support an integrative approach to language study tend to be more highly motivated and overall more successful in language learning. Some CUP students use either one strategy or the other, but most frequently they combine both. Brown makes the point that most students have a combination of both orientations. ${ }^{11}$ He cites the example of international students residing in the United States, learning English for academic purposes while at the same time wishing to become integrated with the people and culture of the country.

Teachers need to understand student's motivational features. Teachers need to know whether their motivation is mostly instrumental or integrative, and what kind of aspects that teachers should pay more attention to. All this has to be done in order to know the leamers better and satisfy their needs. Humanistic education is quite linked to motivation patterns because it focuses on the combination of the subject matter to be learned with the feelings, emotions, experiences and lives of the learners. This kind of education takes students into account and sees them as human beings that are proud of their ability to analyze data and make generalizations. Besides, students do not normally enjoy speaking unless they understand what they are saying,

\footnotetext{
10 G. Crookes \& R. W. Schmidt, "Motivation: Reopening the Research Agenda," Language Learning, (41) 4 (1991): 469-512.

II Brown. 154-55.
} 
but they do get great satisfaction from communicating their thoughts through speech. They like their sentences to come out in a logical sequence, and hope that they bear some relation to the real world. They are deeply reluctant to perform tasks that seem meaningless, and dislike seemingly endless mechanical repetitions. Learners differ greatly, and appear to learn language in various ways. No matter what they are forced to do, they do not learn as much as when they want to do so.

\section{Method $^{12}$}

Ethnography involves the study of a small group of people in their own environment. Rather than looking at a small set of variables and a large number of subjects ('the big picture'), the ethnographer attempts to get a detailed understanding of the circumstances of the relatively few people being studied, who can be from any race or culture throughout the world. The fundamental purpose of ethnography is to vividly recreate the phenomena studied according to the target population.

This research took place in Colegio Universitario de Puntarenas with a group of Tourism students who were taking English III. This class integrates the four skills of language and some level-adapted materials to include culture. The participants were observed for a period of sixteen weeks during four-hour afternoon lessons. This was carried out at least once a week. The first observations were not controlled, whereas the rest were discussed and planned. Twentythree participants were involved in the process since the beginning of this research, but only four were not considered for the final analysis due to their limited presence during the data collection phase or lack thereof. The ethnographic research began by aiming at classroom situations. Later, a further purpose was to analyze and understand the

$12 \quad$ I want to thank Dr. Jorge Quesada Pacheco (Universidad Nacional) for stimulating my interest in ethnographic research and giving me useful insights. 
teaching-learning process and provide other colleagues with useful findings to enhance their students' ability to learn English.

This study consisted of two parts: the first was weekly observations and the second was a set of written interviews that went hand in hand with a professional analysis of a task carried out by the students. The study was carried out with the assistance of two colleagues who contributed significantly to the initial research. ${ }^{13}$

\section{Procedure}

The study followed a process of triangulation. The first step of this process was to hypothesize, based on class observations, guided questionnaires, and the pictures drawn by the students. The second step consisted of two separate analyses of the students' drawings by certified psychologists. Finally, the third source of triangulation was the collection of students' input through written interviews and an open class discussion.

The initial observations of these students took a couple of weeks; the intention was to recognize them as a group. In the beginning they seemed like a standard class with regular students. For the first weeks, there were only customary educational patterns: students coming in late, students not bringing their homework, some students participating, some others not paying attention, some students speaking in English and some in Spanish. After analyzing the first observations, there were certain words that were repetitive such as "motivating," "fun," "exciting"; however, they seemed unimportant at that time. Undoubtedly, there was a common factor: the students were all very motivated during the English class.

One of the colleagues observed the class for about a month and she was able to make a discovery. She observed that my constant use

$\overline{13}$ Professors José Francisco Soto Morera and María Gaitán González (Universidad Nacional,
Costa Rica). 
of endearment terms with my students was eliciting a particular response in the students. Usually in my classes, I give students extra lessons, and try to treat them as politely as possible; this was enabling students to learn the language efficiently. Then there was research on the students' background, classroom environment, the teacher-student relationship, and the students' relationship with other professors that needed to be taken into account.

For this purpose a questionnaire (See Appendix 1) was designed and also the possibility of having the students make some drawings to get more input was proposed. Throughout the process, observations of other professors were also carried out. In these observations, aspects such as gender, personality, teaching styles, student interests, and motivation were significant and related to the research.

Another colleague observed that the class had a significant group personality; this is very uncommon in college environments. Other elements like proxemics, interests, background, housing, age, friendliness, fellowship and others combined with the classroom dynamics enabled them to view me as one of the group, like a big sister. According to his observations, I seemed to be someone who cares about them, an "accomplice," and the professor who gives them a break in their "academic burden."

The students' drawings of the English class were given to one of the psychologists to be analyzed. The results were narrowed down to two main conclusions. First, that a sense of group security was felt throughout the analysis. In several drawings, for example, equality between the teacher-student and student-student relationship was presented. Moreover, the way I speak inside and outside the classroom was much like the students' language, and that brought them closer to me. Another aspect that stood out was that because the class is dynamic, it does not cause stress in the students. The second main conclusion is then that as a teacher I am represented as a figure of value, respect, and authority.

Next, the questionnaires were collected and were found to have a great deal of information. For example, most of them argued that 
English was the most important subject for their major. When referring to past feelings in high school such as their favorite subject and teacher, they surprised us with their answers. There was one who openly said, "My favorite teacher in high school was computer science instructor and she was like a mother to me." Other students agreed on certain physical and emotional characteristics such as brunette, tender, loving, caring, demanding, maternal and strict, among others. All the information was put into statistics and charts to make it easier to understand (See Appendix 2).

Other observations took place in different settings. Although students do not seem to be stressed in the class, other environments could be more relaxed and interesting to observe. Besides that, there might be other behaviors that one might omit because of customary routines. At that point, there was something positive going on in the class that was open and directly affecting the learning of the language. My colleagues commented that this class was different from the others. The students were motivated, but there was a need to find out where that motivation was coming from. The only aspect that was certain is that I care about them and they can see that. One of the main questions here was whether it was possible that the caring and sharing were making them learn faster and better.

The time came to tell the students about the project. ${ }^{14}$ They were given a formal questionnaire to be answered (See Appendix 3). After they finished giving their written opinions, there was an open discussion about their answers. This conversation was taped so that no details would be missed. The whole process took an hour and twenty minutes. Students were told what ethnography was and information was slowly elicited. In general, learners agreed with the ideas of the research project; nonetheless, students gave some other interesting insights on other aspects not considered previously.

$14 \quad$ I am particularly grateful to the CUP students who were my source of information and inspiration for this article. 


\section{Findings}

The observations, the instruments, the drawings, the professors, the analysis, the methods, the students and the long hours working and analyzing data made this project significantly fruitful. The following series of categories were established during the research process and their selection was made with regards to the previous variables.

\section{Personality and Age}

The first variable to be considered important was personality. In the observations, it was pointed out that the teacher's personality influenced the students' learning process. According to the psychologists' analyses, this hypothesis was confirmed. Both psychologists agreed that the drawings reflected positive feelings towards the teacher's personality. They found in the drawings that the teacher was the most popular figure drawn. It was described as highlighted, first, large and predominant. This is interpreted as a valued element representing good student-teacher relationship mainly because the representation is more of a close, trustworthy friend; someone who represents an older role model to follow. In regards to the students' point of view, they favored personality as a related link to their learning. They described the teacher as open-minded, creative, and concerned about their learning and personal lives. A relevant aspect of the teacher's personality is that she creates a safe environment where people do not feel embarrassed or afraid to make mistakes, which allows them to use the language freely. The teacher's personality, as well as her age, also contributes to a good teacher-student interaction.

In the same way, students believe that the teacher's age has also been an aspect that has improved their learning process. Many relate her age to entertainment, fun, empathy, friendship, and trust. The fact that the teacher is a graduate student allows her to understand their behavior and the problems young people have, like living alone, having a job and studying at the same time. Students also acknowledge the fact that she can have fun and make jokes, but also be strictand have them do the work they are supposed to do. 


\section{Teacher's Endearment Terms}

In the observations, it was discovered that the teacher treats the students kindly and lovingly. This was shown through how she refers to them as her "babies," "beautiful people," and other names, which causes a very positive reaction. Students always smiled when they were called by these names, and we were amused by the fact that other teachers also started using these same terms of endearment and the students themselves would use these nicknames with each other as well. The first psychologist's analysis came to the same conclusion by noticing how the students drew her teacher using those names, and other affective terms. This led them to conclude that they certainly feel safe and cared for in the English class because of such kind treatment.

The students express this likewise in both their written and oral replies, but there is an odd tendency of denial when they have to externalize it aloud. All in all, they agree that they feel comfortable in the class, and the use of affectionate terms leads them to learn the language better, acknowledging also that they are more communicative with her and vice versa. So, they feel they can ask any questions without feeling embarrassment. Related to this, they see no obstacles between teacher and student, and it makes their learning accessible. By using these names, many students express that their motivation is improved. This is of particular significance in Costa Rica where names and terms of endearment are used much more frequent that in Englishspeaking countries. A mother-like teacher encourages them to progress, and so not let her down because, as they say, "A mother teaches and gets worried about their well-being." Conversely, a few students recognize this fact as well, but they believe that the improvement lies more on the fact that the teacher is strict, and that each one must take the control of his or her own learning process. Finally, one student summarizes the class's feelings towards their teacher. She wrote the following in the written interview: "The truth is that it is very important because mothers somehow teach us to live, to speak, to study and to behave ourselves, and Patricia, she gave us that educational concern and tenderness." 


\section{Favorite High School Teacher in Comparison to English Teacher Observed}

During the observations, students were given two instruments to gather information essential for our hypotheses. One of them was about personal information, family relationships and high school experiences. One question explicitly asked the students who their favorite teacher was and why. Students listed a set of physical and emotional characteristics that they found in them. Some of these characteristics match the teacher's personality; for example, she is kind, understanding, strict, and academic and emotionally concerned, among others. Students' observations, on the other hand, did not support some of our preliminary hypotheses. Some of them agreed on the fact that their favorite high school teacher was like the CUP teacher, and that obviously improves their English learming. However, most stated that it had nothing to do with it. The students who expressed a clear relationship with the high school teacher and the CUP teacher stated that there was a motherly relationship, a caring, non-stressful environment, a good student-teacher relationship, motivation, friendship, love, patience, and a role model to follow. The rest suggested that their high school teacher was not as dynamic and professional as the CUP teacher evaluated. Two students affirmed that they preferred Patricia to their favorite high school teacher. One student even said that it was difficult for her to remember her favorite, but in the CUP teacher's case she would never forget her. Other patterns suggested by the students include the teacher's unintimidating way of approaching them, which enables them to perform better in the class. Other students also added something new to this variable; they expressed that learning a language depends on each individual's effort and dedication to it, but they emphasized that the teacher in the class plays a fundamental role. 


\section{Drawings}

Another way of collecting information was asking the students to make a drawing about the English class. The drawings were taken to two psychologists. The psychologists took into account aspects such as the size and type of the drawings, the graphic content, the human and non-human images, the strokes (weak or strong), the situational elements and others, which represent the tendencies in the students' behavior. In general terms, the drawings showed the positive features of the class.

Neither the observations nor the psychologists' professional experience alone could ever interpret the students' pictures. During the discussion about the drawings, we got the real insights. For instance, the student who drew a beach stated that he considers the beach as an attractive, relaxing place which is what the English class represents for him. This is more significant when we remember that Puntarenas is a beach town. Another student explained the drawing about the road with obstacles that led to a lit candle with the word success written on top of it. She said that the candle represented the goal to be achieved in the English class, and the obstacles represented exams and tests and other problems regarding the learning process. The student who drew vegetables explained that they are healthy, and so are the English classes. In addition, she drew some people working out who represented an active class. Finally, the explanation of the strawberry drawing: the student expressed that she did not know much about the class because it was the first time she was taking it; however, she took into account what other students had said about it and decided to draw a happy dancing strawberry symbolizing how cool the class had been described to her.

\section{Relaxed, Homelike Class Atmosphere}

Throughout the observations and group discussions, the fact that most of the students are living far away from home was considered to be an important factor. In the analyses, many drawings interpreted the 
English class as a vital, cozy, comfortable place to be. After reading the students' responses, many wrote that indeed the class is relaxed, homelike, and fun; others mentioned that the English class is like a second family to them because of the collective feeling existing between the teacher and the students. Nevertheless, they made it clear that this was by no means connected to the fact that they are far away from home.

\section{Motivation and Humanistic Education}

The category of motivation as the direct success of the students' English abilities was and is the actual core of this research. In the analyses, this idea was supported in different ways. First, a sense of group security was felt. Second, the English class does not cause stress in the students. Third, the class was interpreted as a motivating element in their lives because they can feel free to share with one another. Finally, the first psychologist wrote that the professor is represented as a person who guides, leads, motivates, explains, but most of all insists and worries about her students' success in the process of acquiring and learning English. Surprisingly, when confronting the students, these previous thoughts were expressed almost word by word. My two colleagues interviewed the students and they highlighted the fact that the teacher's actions motivated them to learn English and go to class. They explained that the teacher makes an effort to teach them the language by giving them vocabulary, by planning creative classes, and even helping less fortunate students by paying for class material, giving them money to come to class, and sometimes to eat, and finding the reasons why they are sometimes unable to come to class or take exams. In addition to educational aspects, they mentioned how the teacher makes an additional effort to get to know them as human beings, and thus understand them better.

Another important factor is other students' motivation; this was explained in different ways. The first related aspect is that they concurred that they have achieved a level of English far beyond their 
expectations. One student said, "I have learned more with Patricia than I did in five years in high school." Another student clearly developed this point, she explained that when she joined this class, she saw how everyone had an excellent proficiency English for their level, and they were close to each other and always made an effort to learn English. A student mentioned that then she was afraid she would not fit in and that she would have to attempt to do so. Many students also spoke about how they like English and also that as future professionals, as tourist guides, "they are nothing without English."

The students all agreed that the teacher worked on developing and maintaining good relationships, showing concern and support for others. This type of methodology gradually created a bond of closeness between the learners and the teacher. To conclude this account of data collected, the students came to the most important finding: that nearly all of the previous categories and others are directly related to motivation and thus to their learning success.

\section{Implications}

The interactions between the group participants reported in this study raise a number of issues that may be useful to future teacher groups. Students' insights are of great benefit for all teachers regardless of the subject they teach. First, concerning the importance of not judging students without any real references make a difference. Many teachers tend to label their students as lazy, bad and irresponsible, thus separating or alienating them from the rest of the group. Nevertheless, when teachers take the time to look into the motives for their actions, trying to help, understand and encourage them, it changes the students' attitudes towards the language making them feel motivated to learn and grow a sense of group belonging. This gives way to the second issue, group unity. In class, when a teacher makes an effort to include, motivate and support all the individuals in a class, and establishes a pattern by example, students tend to follow. The target population was 
subject to this behavioral pattern, which created and kept a strong sense of group unity. When new students were introduced to the class, they were adopted by others and felt the urge to behave the same way. This type of group collectiveness, as stated by the participants, enhances their motivation to come to class and learn English. Third, making students feel comfortable and cared for by the teacher indirectly improves the second language learning process. Students can feel comfortable when they know that they can be relaxed, in a nonthreatening environment where the teacher is flexible, has a good sense of humor but also knows when to get serious and get work done. If groups of teachers come together to discuss and reflect on their teaching, then it will be important for them to think of ways in which they can apply these various types of interactions to improve their SLA instruction.

\section{Final Considerations on the Project}

The teacher, in this project, was a generator of group motivation and positive class environment, which was considered the first basis for the students' English. Some of the essential factors that were present in the class were Cooperative Learning, which according to Jack Richards leads to more dynamic classroom interaction. Some characteristics include "less teacher talk, increased student talk, more varied student talk, more negotiation of meaning, a greater amount of comprehensible input, a more relaxed classroom atmosphere, and greater motivation for learning." 15 In addition to having the teacher as a generator of group motivation, the participants said that they themselves motivate one another for what Thanasoulas described as "several factors that promote [a cohesive learner group], such as the time spent together and shared group history, learning about each other, interaction, intergroup competition, common threat, and active presence of the leader."16

\footnotetext{
5. Brown. 77-85.

16. Dimitrios Thanasoulas, "Motivation and Motivating in the Foreign Language Classroom," The Internet TESL Journal VIII, 11 (2002), accessed 6 March 2004, <http://iteslj.org/Articles/ Thanasoulas-Motivation.html>.
} 
In regards to the teacher creating a positive classroom environment, there are three main causes: the teacher's endearing terms, the teacher's personality and the methodology applied by her. "Since the early seventies, beginning with work of Gardner and Lambert, numerous empirical studies have shown significant correlations between affective factors and proficiency." 17 Similarly, Schumann in his study of neurobiology of affect in sustained deep learning concluded that affect and cognition are inseparable and that positive affective assessment is essential in order for learning to take place. ${ }^{18}$ The teacher never separated the mind from the feelings; instead she integrated them thus humanizing the learning process. As it was shown, for her and her classes it is essential to establish a warm, supportive, accepting and non-threatening climate. Also focusing on the positive aspect was of great benefit for the students.

A teacher's personality influences the students' behavior in many ways. A key element is to establish a relationship of mutual trust and respect with the learners, by talking with them on a personal level. Young's research with language learners suggested that teachers who used humor and created a friendly, supportive, and relaxed classroom atmosphere that encouraged risk-taking were most helpful in alleviating foreign language anxiety and facilitating learning. Setting high expectations for the students and holding them up tothose expectations is a final influencing personality trait. ${ }^{19}$

Schütz and Kanomata suggested a series of methodological strategies that contribute to the positive classroom environment that has caused the learners' English learning success. ${ }^{20}$ Some of the most important characteristics cited by these authors and observed in the

\footnotetext{
$17 \quad$ Gardner \& Lambert, 1972.

18 J. H. Schumann, The Neurobiology of Affect in Language (Malden, MA: Blackwell Publishers, 1997).

19 D. J. Young, "An investigation of students' perspectives on anxiety and speaking." Foreign Language Annals 23 (1990): 539-553.

20 Ricardo Schütz \& Yuzo Kanomata, "A List of Important Qualities that Make a Good Language Teacher," (2003) accessed March 2004, <htpp:// www.sk.com.br/sk-gdins.html>.
} 
class include a friendly relationship in English with each student, good student participation, a goal-oriented class according to the level and interests of the students with creative and original examples, patience, empathy and positive attitude. Also the teacher shows interest in the students by making sure they have the necessary materials, encouraging (but never forcing) them to do homework by welcoming them enthusiastically at all times.

The last concept related to the improved level of the participants' English is the importance they have given to instrumental motivation. This is generally characterized by the desire to obtain something practical or concrete from the study of a second language. In their own words, they clearly gave reference to the idea that "a naturalist guide without English is nothing." In their work experiences and educational field trips, they have acknowledged that as professionals in theirfield, this language is a vital means of survival in the current globalized world.

\section{Conclusions}

Effective teaching leads to effective learning, but more important is the fact that affective teaching leads to effective learning. Language teaching is a very complex concept that has to deal with many different aspects. Instructors tend to think that students are a group of people that come to classes to learn about a language like machines. They are not. They are single individuals, human beings that come to classes to learn about life, feelings and a language. My personal teaching philosophy deals with aspects such as a pleasant class atmosphere, a close teacher-student interaction, and high respect for the individual and his or her feelings.

For some, motivation has to do with many aspects and complex factors that should be taken into account. For me it is simpler than that. Let your students know that you truly care about them, their progress in the language, their personal interests, and their lives. However, in order for that caring to be effective it has to be real; you have to get 
involved in their achievements. How can you do that? Start by remembering names, for example. Silly as it sounds, when you remember students' names, they feel they are important in the class and that the teacher cares about them, and thus improve the learning of the language. The majority of the professors would not remember the students' names, even several weeks after classes have already started. The key lies in getting involved in their interests, and helping them in different ways. Teachers have the solution readily available.

Sometimes it seems that teachers are more concentrated on numbers; for example, the amount of material they have to cover for the exams or contents of the class, or how much time they need for each activity. However, what should be essential here is quality rather than the quantity. Motivation is an elemental key in achieving a goal, especially if we are talking about learning a language. Motivation is the backbone of any classroom. Teachers can and do make a difference in the lives of their students; students can and do change as well. One of the most gratifying things in the teaching profession is the fact that teachers can witness a change in people. A teacher might affect the entire course of a person's life positively or negatively; that is why teachers must seek to affect students' lives in optimistic, constructive ways at all times. A teacher can do a lot to improve the students' motivation, and the effort involved is an essential part of the teaching profession. Teaching will always remain an art in the hands of enthusiastic, sensitive, well-prepared classroom instructors at every stage of the learning process. 


\section{Appendix 1}

\section{Questionnaire Used in Initial Survey}

\section{COLEGIO UNIVERSITARIO DE PUNTARENAS}

Departamento de Turismo

1. Nombre completo:

2. Edad:

3. Lugar de procedencia:

4. Lugar de estadía: _Comparte casa _Comparte apartamento _Residencia _ Viaja

¿Dónde?

5. ¿Trabaja?

no sí ¿Conquién? mente ¿Dónde? siempre _a veces ocasional¿A qué hora?

6. Año de ingreso al CUP:

7. Carreras que ha cursado en el CUP:

8. Financia sus estudios: medios propios ayuda familiar beca otro

(Puede marcar más de una opción)

9. Número de clases que está cursando actualmente:

10. Curso que considera Ud. de mayor importancia en la carrera: 


\section{Appendix 2}

\section{Favorite Teacher's Physical and Emotional Description}

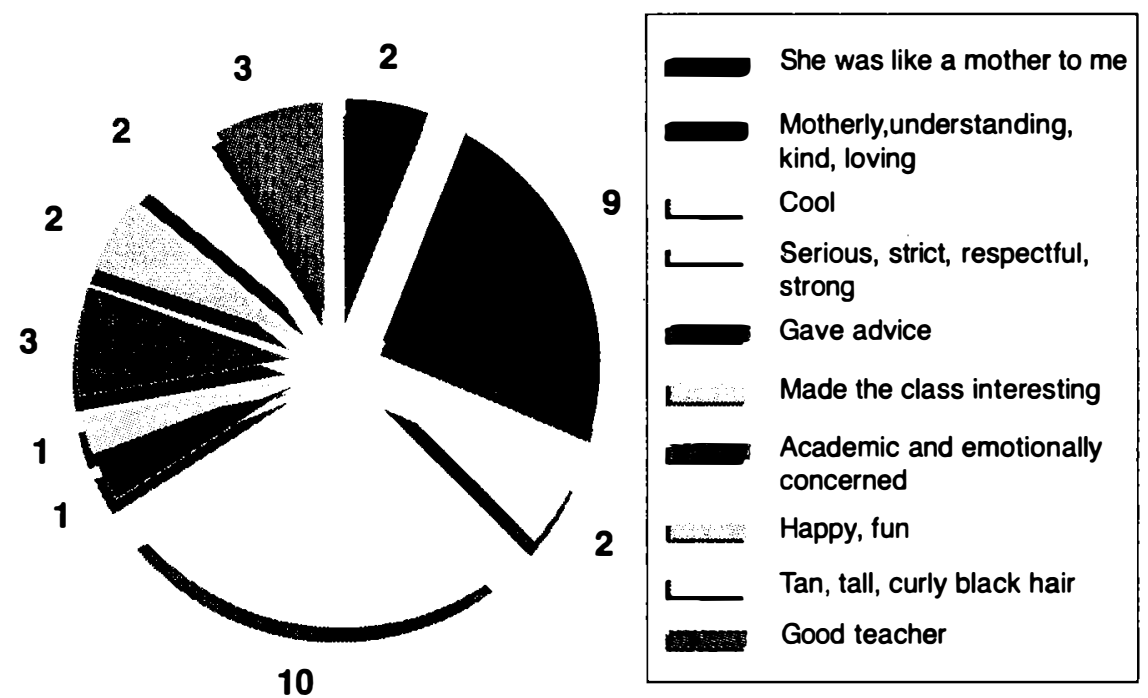

In regard to the teacher's descriptions, the above illustrates them very well. Students wrote more than one answer here. Two students, for example, explicitly said that they liked a specific teacher because she was like a mother to them. Several students mentioned characteristics such as motherly, kind, loving, respectful and understanding. Nineteen students stated positive aspects about their favorite teacher. Students took into account aspects such as the instructor being concerned about their academic performance and emotions, and described her as a happy and fun teacher and who gives them advice. They appreciated a caring person, someone who cared about them from a holistic point of view. 


\section{Appendix 3}

\section{Questionnaire Used in Second Survey}

\section{Universidad Nacional}

Escuela de Literatura y Ciencias del Lenguaje

Maestría en Segundas Lenguas y Culturas

\section{Etnografía en el aula}

En primer lugar, quisiéramos agradecerles la colaboración brindada, y pedirles por última vez un poco de su tiempo. Desde el cuatrimestre pasado algunos de ustedes se extrañaron de la presencia de José y María en su clase de inglés. Como ustedes ya saben, la profesora Patricia está estudiando en la UNA y por lo tanto tiene trabajos que hacer. Para nuestro curso, Etnografía en el aula, debíamos realizar una investigación y escoger a un grupo de estudiantes. Fue por esta razón que Patricia decidió escogerlos por el cariño que les tiene y por lo orgullosa que está de que ustedes han aprendido y mejorado su inglés de una manera significativa en tan pocotiempo. Una vez hecha esta selección, el siguiente paso del proyecto era hacer observaciones de la clase y elegir algún aspecto relevante del proceso de la enseñanza y aprendizaje del inglés. Patricia inició sus observaciones en agosto y luego María fue a observarlos en dos ocasiones. En su segunda observación ella le comentó a Patricia que le llamaba mucho la atención la manera en que ella se relacionaba con ustedes y viceversa. Además le indicó que le impresionaba mucho el nivel de inglés de ustedes para los pocos cursos que han llevado. Esto nos llevó a la idea de guiar nuestro proyecto a la relación entre la profesora, ustedes y su éxito en el aprendizaje del idioma. A la fecha hemos tratado de encontrar la razón o razones de este asunto mediante observaciones y recolectando información de manera indirecta. De todos estos datos replanteamos nuevas ideas y quisiéramos tomar en cuenta sus opiniones para nuestro análisis final. 
Por favor, responda las siguientes preguntas sinceramente y de la manera más abierta posible.

1. ¿Cree usted que la personalidad y edad de la profesora permitió un mejor aprendizaje del idioma?

2. Patricia se refiera a ustedes como "hijos" o "popos". ¿Cree usted que ese trato maternal de Patricia tienen algo que ver con el aprendizaje del inglés?

3. Ustedes describieron a su profesor(a) favorito(a) en el colegio con características parecidas a las de Patricia. ¿Tiene eso algo que ver con su aprendizaje del inglés?

4. ¿Porqué al dibujar la clase de inglés dibujó (y/o escribió) lo que dibujó?

5. Muchos de ustedes viven lejos de sus casas y sus familias. ¿Cree usted que la clase de inglés representa un ambiente relajado, divertido, y/o hogareño?

6. Hemos observado que ustedes están motivados en la clase de inglés. ¿A qué se debe esa motivación? ¿Qué lo motiva a asistir a las clases de inglés? ¿Qué de la clase de inglés lo motiva? 